\title{
The status of forest certification in the Canadian value-added wood products manufacturing sector
}

\author{
by Priyangi Jayasinghe ${ }^{1}$, S. Denise Allen², Gary Q. Bull ${ }^{3}$, and Robert A. Kozak ${ }^{4}$
}

\begin{abstract}
With forest certification on the rise in Canada, a nation-wide mail survey was implemented in 2004 to gain insight into the attitudes of value-added wood products manufacturers towards certification. The majority of firms in this sector $(64.8 \%)$ were not interested in forest certification, and only $17.6 \%$ were involved with forest certification at the time of the survey. Another $17.6 \%$ did express interest in becoming involved within the next five years. Low levels of knowledge and awareness regarding forest certification and a perceived lack of consumer demand for certified forest products were identified as factors contributing to the significant lack of interest in adopting certification. Although uptake remains limited, a cluster analysis identified a sizeable segment of manufacturers (43.5\%) that has a "wait and see" attitude towards forest certification pending future developments in consumer markets. Logistic regression indicated that manufacturer interest in forest certification is linked to both awareness of chain of custody certification and a belief that certification can act as a competitive differentiation tool. Canadian value-added wood products manufacturers that are currently engaged or interested in forest certification tend largely to be ethically motivated and expressed concerns about the future health of forests and sustainable forest management. However, these same respondents were generally doubtful about the ability of forest certification to provide short-term financial gains.
\end{abstract}

Key words: forest certification, chain of custody, value-added wood products manufacturers, Canada

\section{RÉSUMÉ}

Parallèlement à la croissance de la certification au Canada, un sondage postal à l'échelle nationale a été effectué au milieu de l'année 2004 afin d'obtenir une vision de l'attitude des manufacturiers de produits de bois à valeur ajoutée face à la certification. La majorité des entreprises de ce secteur $(64,8 \%)$ ne démontraient pas d'intérêt pour la certification et seulement $17,6 \%$ d'entre elles avaient effectué des démarches de certification au moment du sondage. Un autre 17,6\% a démontré de l'intérêt à obtenir une certification au cours des cinq prochaines années. Les faibles niveaux de connaissance et de sensibilisation en matière de certification et une absence perçue d'exigence de la part des consommateurs ont été identifiés en tant que facteurs contribuant au manque significatif d'intérêt pour l'obtention d'une certification. Même si l'intérêt demeure limité, une analyse des segments a identifié un regroupement marqué de manufacturiers (43,5\%) qui exprime une attitude d'observation de la certification forestière en fonction des développements à venir des marchés de consommation. Une régression logistique a indiqué que l'intérêt des manufacturiers envers la certification forestière est relié à la fois à certification de la chaîne de production et à la perception que la certification peut être un outil de démarcation concurrentielle. Les manufacturiers canadiens de produits de bois à valeur ajoutée qui se sont présentement engagés ou sont intéressés par la certification forestière tendent en grande majorité à être éthiquement motivés et à exprimer des inquiétudes relativement à la santé des forêts dans l'avenir et de l'intérêt pour l'aménagement forestier durable. Toutefois, les mêmes répondants ont exprimé généralement un doute de la capacité de la certification forestière à procurer des gains économiques à court terme.

Mots clés : certification forestière, chaîne de production, manufacturiers de produits de bois à valeur ajoutée, Canada

\footnotetext{
${ }^{1}$ Research Associate, Munasinghe Institute for Development (MIND), 10/1 De Fonseka Place, Colombo 5, Sri Lanka. E-mail: priyangi@mindlanka.org

${ }^{2} \mathrm{PhD}$ Candidate, University of British Columbia, Faculty of Forestry, 2424 Main Mall, Vancouver, British Columbia V6T 1Z4. E-mail: sdallen@interchange.ubc.ca

${ }^{3}$ Associate Professor, University of British Columbia, Faculty of Forestry, 2424 Main Mall, Vancouver, British Columbia V6T 1Z4. E-mail: gary.bull@ubc.ca

${ }^{4}$ Associate Professor, University of British Columbia, Faculty of Forestry, 2424 Main Mall, Vancouver, British Columbia V6T 1Z4. E-mail: rob.kozak@ubc.ca (corresponding author).
} 


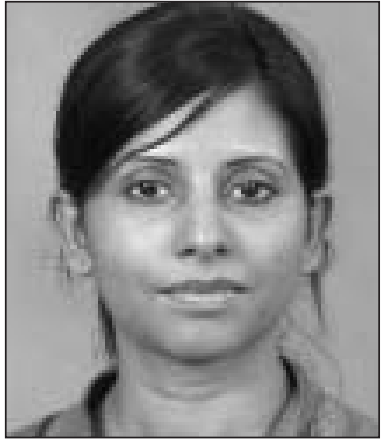

Priyangi Jayasinghe

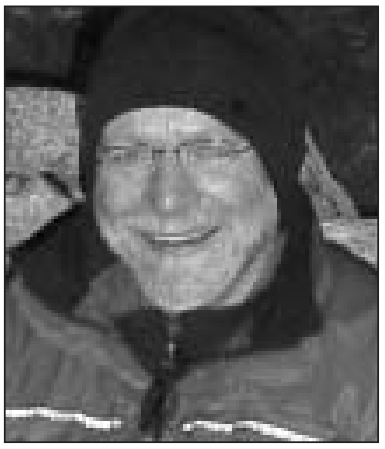

Gary Q. Bull

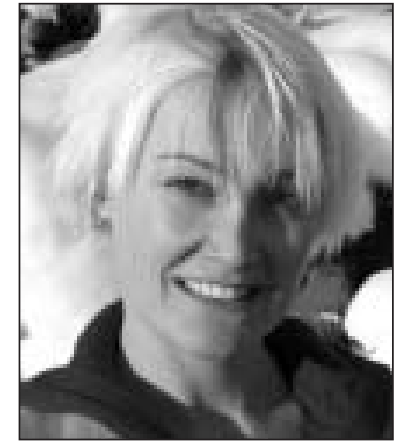

S. Denise Allen

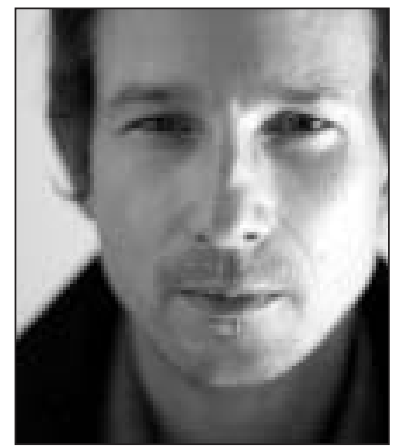

Robert A. Kozak

\section{Introduction}

Since its inception just over a decade ago, forest certification has undergone a transformation from a marginal to a mainstream practice. Between 2000 and 2003 alone, the area of certified forests worldwide doubled to approximately 150 million hectares (WRI 2005, UNECE/FAO 2003). Uptake of forest certification is particularly noteworthy in Canada, where certified area now comprises about $95 \%$ of managed forests nationally and a significant proportion of certified area globally (Abusow 2003, 2006). With the Forest Products Association of Canada (FPAC) working towards further increasing the current area of certified forests (Abusow 2003) and certain provincial governments (e.g., Ontario) making forest certification mandatory, this growth trend is expected to continue.

Although market acceptance of certified forest products is not keeping pace with growth of certified areas globally (UNECE/FAO 2003), demand for certified forest products is reportedly on the rise. Large retailers and buyers, such as B\&Q (United Kingdom), Home Depot (United States), and Ikea (Sweden), have changed their business strategies to include purchasing certified products (IBM Business Consulting Services 2003) and there is a growing number of buyergroups committed to procuring only certified wood (UNECE/FAO 2003). Consumer segments favouring certified forest products have also emerged in many parts of the world (Ozanne and Vlosky 1997, Forsyth et al. 1999, Veisten 2002, Kozak et al. 2004, Archer et al. 2005).

From a marketing perspective, forest certification is a relatively simple and straightforward proposition. However, it is not driven solely by consumer demand. A broad range of stakeholder participation and support from supply chain actors, consumers, non-governmental organizations (NGOs), and academia is crucial to making forest certification a legitimate and influential mechanism for promoting sustainable forest management (SFM) (Bass and Simula 1999, Cashore 2002).

Although wood products manufacturers are clearly important stakeholders with impacts on both the production of and markets for certified forest products, there has been limited research into their acceptance of certification. Insight into the status of forest certification within a wood products manufacturing context is vital to better understanding further development of certified forest products markets and the potential uptake of forest certification schemes among producers. There is a particular dearth of information on secondary producers of higher value wood products, and the Canadian value-added wood products sector is certainly no exception.

The growing importance of the Canadian value-added wood products sector and the lack of related forest certification research suggest a need for closer investigation of the dynamics of forest certification in this sector. Recent research on certified forest products markets indicates potential business opportunities for value-added manufacturers (Vlosky et al. 2003, Kozak et al. 2004), but little else is known. This study was, therefore, broadly framed around better understanding why a value-added manufacturer would or would not be interested in forest certification. Two objectives were specifically addressed in this study:

1) to evaluate the current levels of adoption, interest, and knowledge of forest certification among value-added manufacturers in Canada; and

2) to assess Canadian value-added manufacturers' attitudes towards forest certification in general, with particular emphasis on the perceived benefits and challenges of forest certification.

\section{Background}

The forest certification movement represents a larger regulatory policy shift in an era of globalization as production supply chains expand beyond national borders and new forms of accountability for global business beyond traditional government laws and regulations are required (Bartley 2005, Cashore et al. 2005). In the dawn of neo-liberal ideologies and increased public concern for the environment, governments, environmental non-governmental organizations (ENGOs), and firms alike have turned to markets, and forest certification in particular, as effective policy tools (Ronit 2001, Bartley 2005, Cashore et al. 2005).

Forest certification is based on a market model that expects a cascade effect of consumer demand down the forest products supply chain for products manufactured from sustainably managed forests (Bass et al. 2001). Fundamentally, consumer demand for forest certification is driven by buyers shopping for ethics in forest management in addition to other, more tangible product attributes (Bartley 2005). That said, much of the support for forest certification in recent years is arguably the result of larger retailers whose corporate images have been threatened by ENGO campaigns (Ozanne and Vlosky 1997, Hansen and Juslin 1999).

Forest certification provides a framework for linking such environmentally conscious consumers with "good" firms that practise SFM through two avenues. Forest land management certification certifies firms' adherence to SFM standards 
through independent, third-party auditing and monitoring procedures. Chain of Custody (COC) certification identifies, monitors, and certifies custodianship of forest products from certified forests along the globalized complex of forest product supply chains, producing a credible end-product label for consumers (Bass and Simula 1999). Supply chain actors seeking a marketplace advantage, such as forest managers and producers, can, therefore, use certification as a mechanism for communicating their good forest management practices to conscientious consumers. Conversely, consumers can use certification as a means of holding wood products suppliers accountable for forest exploitation (Bass and Simula 1999, Cashore 2002). Consequently, forest certification can be considered both a marketing tool (Kärnä 2003) and a form of non-governmental regulation of forest management (Cashore et al. 2005).

Forest certification can also act as a communication tool. Since the publication of Silent Spring (Carson 1962), public concern about environmental degradation has been on the rise (Sale 1993). As a result, many firms have developed products targeting environmentally and socially conscious consumers. In addition to other strategies, such as claims about corporate social and environmental responsibility, the forest products industry has employed third-party forest certification (specifically COC certification) to communicate with such consumers (Bass 1997, Ozanne and Vlosky 1997). A great deal of research has indicated that these environmentally conscious consumers may be willing to pay moderate price premiums for certified forest products (e.g., Read 1991, Ozanne and Vlosky 1997, Bass and Simula 1999, Forsyth et al. 1999, Spinazze and Kant 1999, Bass et al. 2001, Bigsby and Ozanne 2002, Veisten 2002). However, there is also consensus among researchers that actual consumer behaviour does not necessarily reflect their reported willingness to pay (McGuire 1985, Sheth and Parvatiyar 1995, Hansen 1997, Anderson and Hansen 2004). Nonetheless, two clear trends are evident: (1) knowledge gaps and generally low levels of awareness regarding forest certification and its connection to SFM are key reasons for low consumer support (Gronroos and Bowyers 1999, Archer et al. 2005); and (2) the majority of certified forest products manufacturers currently do not receive any price premiums (Humphries et al. 2001, Jensen et al. 2003). It appears that the willingness-to-pay premiums are product-dependent, with higher value wood products like furniture standing a better chance of commanding price premiums than commodity goods like lumber (Spinazze and Kant 1999, Kozak et al. 2004). Even though some market "disconnects" may be occurring, recent research also indicates that some consumers may be more likely to purchase certified forest products as they learn more about forest certification and what it entails (Kozak et al. 2004).

Scepticism regarding the purported market benefits and financial gains of certification has slowed global uptake of forest certification as a strategic tool among some forest products manufacturers (Hansen 1997, Hansen and Punches 1999, Prakash 2002, Takahashi et al. 2003, UNECE/FAO 2003, Hubbard and Bowe 2004, Bartley 2005, Vidal et al. 2005). Immature markets, the indirect nature of most benefits, and certification being an unfamiliar concept and process are other commonly cited reasons for a lack of manufacturer support (Humphries et al. 2001, Vidal et al. 2005). The cost of obtaining COC certification seems to be another crucial barrier (Vlosky and Ozanne 1998, Hubbard and Bowe 2004, Vidal et al. 2005), with many companies not being willing to bear the short-term expenses of establishing such systems without the ability to pass it onto customers via price premiums (Vlosky et al. 2003). The limited supply of certified wood is another hurdle (Bull et al. 2001), particularly for valueadded manufacturers who cannot secure a consistent (certified) supply of the individual tree species required for their products (Miller 2002). Lastly, company-specific factors, such as size, location, and sectoral infrastructure (i.e., value-added manufacturers, primary manufacturers, logging contractors, land owners, etc.), can also influence corporate decisions to adopt forest certification (Vlosky and Ozanne 1998, Takahashi et al. 2003, Vidal et al. 2005).

Nonetheless, many forest products companies perceive the benefits derived from forest certification to outweigh the $\operatorname{costs}^{5}$. For some of these companies, endorsing forest certification provides them with the satisfaction of supporting the sustainability of natural forest resources and, more broadly, society at large (WWF 2000). As such, it may also serve to improve their corporate images and access to markets ${ }^{6}$ (Hansen and Punches 1999, Hubbard and Bowe 2004). Research also suggests that the adoption of forest certification may be driven, in part, by firms being ethically and morally motivated to integrate environmental and social aspects into their marketing plans (Prakash 2002, Cashore et al. 2004), even though these actions are more likely to provide economic benefits in the long, versus short, term (Hart and Ahuja 1997, Menon and Menon 1997). Some of the more tangible benefits of forest certification, especially COC certification, include superior supply chain management performance (via improved communications, inventory controls, and market knowledge), transparency for investors, and ultimately, reduced costs and increased profitability (Groves et al. 1996, Mentzer et al. 2001, Vidal et al. 2005).

From a supply chain perspective, existing forest certification research has tended to focus upon implications for forest management, market opportunities, or the production of commodity goods (especially lumber and pulp and paper). Investigation into the dynamics of forest certification in the context of the value-added wood products sector has only recently been undertaken (e.g., Vlosky et al. 2003, Kozak et al. 2004).

In a landscape of forest products manufacturing otherwise dominated by the production of commodity goods like dimension lumber, panels, and pulp and paper, the valueadded wood products sector is emerging as an important engine in the Canadian economy. Value-added, or secondary,

\footnotetext{
${ }^{5}$ Studies have typically focused on larger producers of commodity products with their own forestry operations, and not downstream value-added manufacturers.

${ }^{6}$ For instance, the Leadership in Energy and Environmental Design (LEED) Green Building Rating System ${ }^{\circledast}$ (USGBC 2005) has the potential to increase demand for certified wood and provide new markets for all parties involved in building projects, including wood products manufacturers, specifiers (architects, structural engineers, and interior designers), builders, and distributors. As the LEED system gains popularity in the commercial building sector (Ervin 2002) and expands into U.S. and Canadian commercial interior and housing markets (Libby 2004), it could create an important market opportunity for certified wood products in both the primary and value-added manufacturing sectors.
} 
wood products are goods produced by transforming raw materials (primary wood products) into higher value (typically non-structural, appearance) wood products (Vlosky et al. 2003). The assortment of value-added wood products is diverse, including finished building products, some engineered wood applications, mouldings, millwork, furniture, and cabinetry, to name just a few examples (Kozak and Maness 2001). While the value-added sector in Canada tends to be made up of privately owned small- to medium-sized enterprises (SMEs), it is an important sector to the national economy, providing more than 200000 jobs in 2001 (WMC $2006)$ and generating approximately $\$ 8$ billion (CDN) in shipments in 2003 (Industry Canada / Strategis 2006).

As stated above, forest certification research in the context of value-added production remains scant. A recent U.S. study found only a small percentage of American value-added manufacturers using certified wood products, and attributed this lack of traction to companies being unfamiliar with forest certification (particularly COC) and the corporate philosophies of many value-added wood products manufacturers not being conducive to the adoption of certification schemes (Vlosky et al. 2003). However, Kozak et al. (2004) reported that the potential to develop markets for certified value-added products does exist in Canada, especially if further efforts are made to improve consumer awareness of forest certification.

Given the importance of the value-added sector and the influence of forest certification in Canada, it is surprising that research considering these issues in concert is so limited. Addressing this knowledge gap concerning the status of forest certification amongst Canadian value-added wood producers is seen as critical and timely, especially in light of the fact that value-added producers are situated in the middle of the forestry supply chain, both as potential customers and suppliers of certified wood products.

\section{Methods}

The purpose of this study was to analyze current attitudes towards forest certification in the Canadian value-added wood products sector, with the aim of describing current trends and manufacturers' views and experiences. To that end, data were collected using a mail survey (similar to the one implemented by Vlosky et al. 2003) directed at valueadded manufacturers across Canada and administered in late 2003 / early 2004.

The survey itself was designed and implemented in accordance with methods prescribed by Dillman (1978) and Babbie (2001) in order to maximize response rates and minimize non-response bias. The survey was in English ${ }^{7}$ and comprised four sections, targeting a comprehensive understanding of corporate experiences with various aspects of forest certification initiatives. Section 1 gathered information for profiling value-added manufacturing companies, including location, size, number of employees, types of products manufactured, and so on. Section 2 investigated manufactur-

\footnotetext{
$\overline{{ }^{7} \text { Many value-added producers are located in Quebec and Atlantic }}$ Canada and French is their primary language. Budgetary constraints precluded the development of a French version of the survey and this may have resulted in a lower response rate in those regions and introduced some bias in this study.
}

ers' awareness of, attitudes towards, and levels of interest in forest certification ${ }^{8}$. Section 3 asked those companies currently considering or engaged in forest certification to identify reasons for their interest in certification and attitudes towards the benefits and costs of certification. Finally, Section 4 collected information related to manufacturers' views on forest certification in general. Prior to implementation, the survey was rigorously pre-tested among peers and colleagues to address issues of clarity, flow, and time to completion.

The survey was mailed out to $1000^{9}$ value-added manufacturers across Canada in a series of four time-lapsed mail outs (Dillman 1978). A stratified random sampling scheme was applied to a comprehensive sample frame of 2607 companies compiled from four sources: the Quebec Wood Exporting Bureau (QWEB), the BC Wood Specialties Group, the Wood Manufacturing Council (WMC), and Forintek Canada Corp. The sample frame was then stratified into five regions ${ }^{10}$ based on an adjusted ${ }^{11}$ proportional allocation scheme: Western Canada (226), the Prairies (62), Eastern Canada (656), Atlantic Canada (54), and Northern Canada (2). Surveys were generically addressed to the "value-added wood products manufacturer" in hopes that the appropriate person (at a high enough level) in each firm would respond ${ }^{12}$.

The survey data collected were analyzed using SPSS (version 11.0) statistical software. Frequencies and means (with $95 \%$ confidence intervals) were used to summarize the data, and significance tests ( $\mathrm{t}$-tests and z-tests at $\alpha=0.05$ ) were conducted to detect differences between means and proportions. This study also included two multivariate analyses. A cluster analysis was used to identify the shared characteristics of companies most (and least) likely to adopt forest certification, while logistic regression (LR) was used to determine which variables had the most influence on whether a company was interested in forest certification.

\footnotetext{
${ }^{8}$ Here, simplified definitions of forest land and COC certification were provided in the survey to better frame responses to these questions, as follows: "Forest certification confirms that wood products come from sustainable managed forests. Chain of custody certification confirms that sustainably managed wood was used in the production of wood products". These definitions were kept intentionally brief to minimize any risk of influencing the respondents and biasing their responses to knowledge-based questions related to certification (Vlosky et al. 2003, Archer et al. 2005). ${ }^{9}$ This number was based largely on budgetary constraints, but was deemed appropriate given the precision requirements of this study. ${ }^{10}$ In this study, provinces were collapsed into five regions (strata) to ensure a large enough sample size in each: Western Canada = Alberta, British Columbia; the Prairies = Manitoba, Saskatchewan; Eastern Canada = Ontario, Quebec; Atlantic Canada $=$ New Brunswick, Newfoundland and Labrador, Nova Scotia, Prince Edward Island; Northern Canada $=$ Northwest Territories, Nunavut, Yukon.

${ }^{11}$ To ensure that underrepresented regions were sufficiently sampled, the numbers of companies sampled in the Prairies, Atlantic Canada and Northern Canada were doubled, and the numbers in the other regions were adjusted accordingly to maintain a total sample size of 1000 .

${ }^{12}$ This generic approach was used because specific names of CEOs or managers could not be obtained. It should be noted that, while the basic unit of analysis in this study is "companies", the results truly reflect the opinions and attitudes of the persons within each company responding to the survey.
} 
Table 1. Tests for non-response bias between early and late respondents.

\begin{tabular}{lccc}
\hline Variable & $\begin{array}{c}\text { Early Respondents } \\
(\boldsymbol{n}=\mathbf{5 0})\end{array}$ & $\begin{array}{c}\text { Late Respondents } \\
(\mathbf{n}=\mathbf{6 5})\end{array}$ & $\begin{array}{c}p \text {-value } \\
(\alpha=0.05)\end{array}$ \\
\hline Mean percentage of raw materials used: & & $19.0 \%$ & 0.18 \\
$\quad$ Reconstituted wood products & $21.0 \%$ & $13.2 \%$ & 0.12 \\
Plywood and veneer & $10.5 \%$ & $26.5 \%$ & 0.23 \\
Softwood lumber & $27.3 \%$ & $27.2 \%$ & 0.15 \\
Hardwood lumber & $30.8 \%$ & $4.9 \%$ & 0.11 \\
Dimension parts and components & $2.9 \%$ & $9.6 \%$ & 0.17 \\
Other & $7.5 \%$ & 168.6 & 0.20 \\
Mean number of employees & 142.3 & 0.36 & 0.19 \\
Proportion interested in certification & 0.33 & & \\
\hline
\end{tabular}

\section{Results}

\section{Response rate and non-response bias}

Of the 1000 questionnaires mailed out, 125 were returned as either undeliverable (i.e., companies that had moved) or by companies for which the survey was not applicable (i.e., no longer in the business of value-added wood products). In total, 115 completed surveys were returned for an overall response rate of $13.14 \%{ }^{13}$. In any survey analysis, statistical inferences must be drawn from responses that represent only a subset of the population. The validity of this approach is questionable when the non-respondents are significantly different (in their attitudes or any other manner meaningful to the study) from participating respondents. If this so-called "non-response bias" occurs, inferences onto the population under study are dubious (Dillman 1978). In this study, late respondents (those responding to a subsequent rather than the initial mailout) were considered proxies for non-respondents, allowing for statistical testing against the early respondents to determine whether or not non-response bias was present (Armstrong and Overton 1977, Lambert and Harrington 1990, Wilson 1999).

Early and late respondents were compared on the basis of some of the reported company characteristics. Levels of general interest in forest certification were also assessed in order to ensure that there were no biases present regarding the primary objective of this study. Statistical tests of difference ( $\alpha=0.05)$ were conducted on three variables: mean percentages of various wood products used as raw materials (by value), mean number of employees, and proportion of companies interested in forest certification (including both those currently involved and those planning to become involved with certification). These values are summarized in Table 1, along with the $p$-values from statistical difference tests between early and late respondents. Since there were no significant differences between early and late respondents, there is no evidence to suggest the occurrence of non-response bias and statistical inferences may, therefore, be drawn for the larger population of Canadian value-added wood producers.

\footnotetext{
${ }^{13}$ While there is no general agreement as to what constitutes an acceptable response rate (Babbie 2001, Dennis 2003), mail survey response rates of $10 \%$ to $30 \%$ are not uncommon in marketing research (Boyd et al. 1989).
}

\section{Company profiles}

Survey responses were solicited from value-added wood producers all across Canada. The majority of respondent firms were located in Western Canada (51.9\%), followed by Eastern Canada (35.8\%), the Prairies (6.6\%), and Atlantic Canada $(5.7 \%)^{14}$. Although the types of value-added wood products manufactured by these companies were extremely varied, value-added products accounted for approximately $80 \%$ (by value) of respondents' most important product lines. This result, coupled with the national distribution of firms in the final sample, is interpreted as indication that coverage error was minimized and the appropriate (representative) companies responded to the survey.

As expected, most (48.7\%) companies were small-to medium-sized enterprises (SMEs), employing 20 or fewer workers. Almost one-fifth of the firms surveyed (19.8\%) had more than 100 employees (FTEs), with only 3.6\% employing more than 1000 people. Sixty-six percent $\pm 6.5 \%$ of the production of finished wood products (by value) is sold domestically, while $33.4 \% \pm 6.5 \%$ is exported. The most commonly used raw material (by value) in the Canadian value-added sector is hardwood lumber (mean proportion of $28.8 \% \pm 6.2 \%$ ), followed closely by softwood lumber (26.6\% $\pm 6.9 \%)$. Reconstituted wood products like particleboard and medium density fibreboard (MDF) account for $19.9 \% \pm 5.4 \%$ of use, on average, followed by plywood and veneer at $12.0 \% \pm 3.7 \%$. Other products, such as dimension parts and components, account for less than $10 \%$ of the value of raw materials used (by value).

Canadian value-added wood products manufacturers were also asked to rank (from 1 to 3 ) the importance of 12 business issues, including environmental concerns. The proportions of responses assigned to each rank were plotted in Fig. 1 as a way of showing the relative importance that these companies collectively placed on these business issues. Quality of finished products and financial returns are clearly the most important consideration for Canadian value-added wood products firms - not a surprising result, given the highly competitive nature of the sector. While present and future health of forests and company image placed in the mid-

${ }^{14}$ There were no responses from the two firms in Northern Canada. 


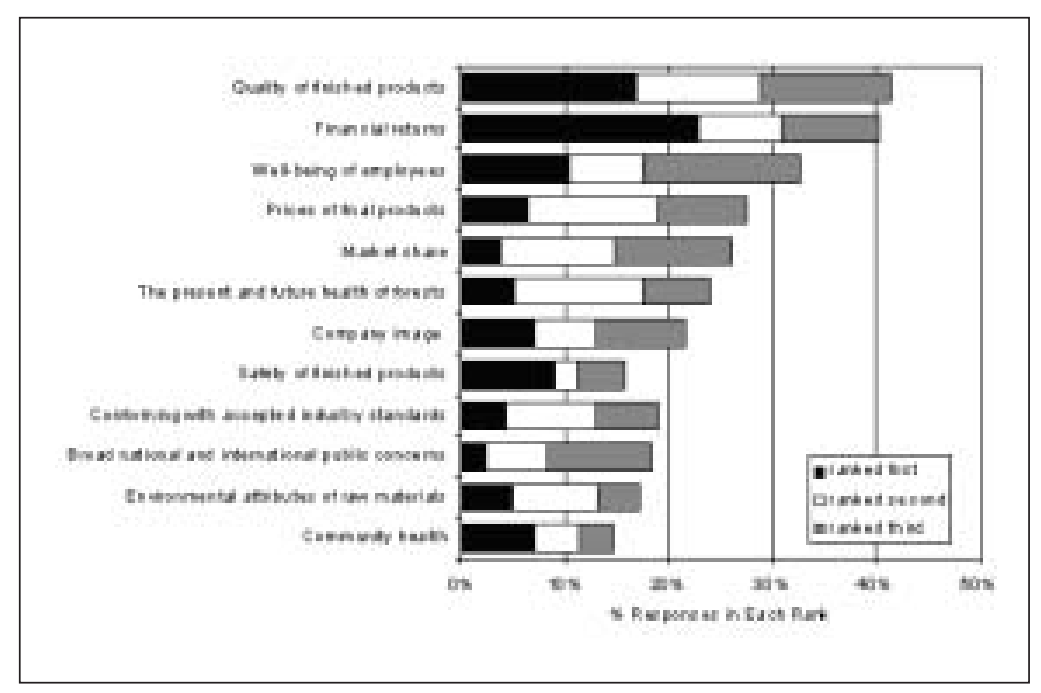

Fig. 1. Importance of various business issues to respondent companies (by proportion of responses ranked first, second, and third).

dle of these business considerations (but behind more pragmatic business concerns like well-being of employees, prices of final products, and market share), most issues directly related to forest certification (community health, environmental attributes of raw materials, conforming with accepted industry standards, and broad national and international concerns) were ranked at the bottom.

\section{Uptake of / interest in forest certification}

Three categories were used to assess uptake (level of interest) of forest certification within the Canadian value-added wood products sector. Table 2 summarizes the frequencies and proportions (including 95\% confidence levels) of companies identifying themselves as currently involved in certification, interested in becoming involved in certification (within the next five years), or not interested in certification at this time $(\mathrm{n}=108)$. The majority $(64.8 \%)$ of respondents stated that they had no interest in becoming involved in forest certification. The remaining responses were evenly split between companies currently involved in certification (17.6\%) and another $17.6 \%$ with plans to become involved in certification in the near future. In general, COC certification was less prevalent than the use of certified wood materials, although some respondents claimed to use a combination of both types of certification. A similar trend was evident among companies intending to become certified within a fiveyear period.

Table 3 shows value-added manufacturers' interest in forest certification by location. In all four regions, the majority of firms surveyed were not interested in forest certification. At the time of survey, no certified companies were identified in the Atlantic Canada region. Overall, the Prairies had the lowest level of interest in certification, while Western Canada had the highest.

The question of what makes a value-added manufacturer interested in forest certification was central to this study and, to that end, binary logistic regression ${ }^{15}$ was used to determine which variables were significant predictors of whether a company was interested in certification. The analytical objective of fitting a model to the dataset was exploratory, as opposed to hypothesis testing (Field 2000, Menard 2002). Consequently, the stepwise method ${ }^{16}$ was used to investigate five sets of predictor variables: region; number of employees; proportion of sales destined to international markets; awareness of forest certification (four variables) and attitudes toward forest certification (11 variables).

The resulting model (Table 4 ) had a reasonably accurate classification rate of $76.5 \%$, an acceptable Nagelkerke R Square value of 0.420 , and a $-2 \log$ likelihood chi-square statistic of 107.805, all of which indicate a strong data fit in the model. Moreover, the confidence intervals for the $\operatorname{Exp}(\mathrm{B})$ values do not pass through zero, meaning that they can be

\footnotetext{
${ }^{15}$ Logistic regression is a technique commonly used to predict group membership (outcome variables) using predictor variable(s) (Tabachnick and Fidell 2001). Binary logistic regression is used when the group membership (or the outcome variable) is a dichotomy (Field 2000, Tabachnick and Fidell 2001).

${ }^{16}$ The forward and backward stepwise methods produced identical results. As such, only forward stepwise results are presented here.
}

Table 2. Levels of interest in forest certification.

\begin{tabular}{|c|c|c|c|}
\hline evel of Interest & $\begin{array}{l}\text { Frequency } \\
(\mathrm{n}=108)\end{array}$ & $\begin{array}{l}\text { Relative } \\
\text { Frequency }\end{array}$ & $\begin{array}{c}95 \% \\
\text { Confidence } \\
\text { Interval }\end{array}$ \\
\hline ompanies currently involved with certification & 19 & $17.6 \%$ & $\pm 0.07 \%$ \\
\hline With COC & 6 & $5.6 \%$ & $\pm 0.04 \%$ \\
\hline Without COC & 9 & $8.3 \%$ & $\pm 0.05 \%$ \\
\hline A combination of both & 4 & $3.7 \%$ & $\pm 0.04 \%$ \\
\hline ompanies interested in becoming certified within five years & 19 & $17.6 \%$ & $\pm 0.07 \%$ \\
\hline With COC & 7 & $6.5 \%$ & $\pm 0.05 \%$ \\
\hline Without COC & 4 & $3.7 \%$ & $\pm 0.04 \%$ \\
\hline A combination of both & 8 & $7.4 \%$ & $\pm 0.05 \%$ \\
\hline ompanies not interested in certification & 70 & $64.8 \%$ & $\pm 0.09 \%$ \\
\hline
\end{tabular}


Table 3. Company interest in forest certification, by location.

\begin{tabular}{|c|c|c|c|c|}
\hline Level of Interest & $\begin{array}{l}\text { Western Canada } \\
(\mathrm{n}=55,51.9 \%)\end{array}$ & $\begin{array}{c}\text { Prairies } \\
(\mathrm{n}=7,6.6 \%)\end{array}$ & $\begin{array}{l}\text { Eastern Canada } \\
(\mathrm{n}=38,35.8 \%)\end{array}$ & $\begin{array}{c}\text { Atlantic Canada } \\
(\mathrm{n}=6,5.7 \%)\end{array}$ \\
\hline Currently certified & $18.2 \%$ & $14.3 \%$ & $21.1 \%$ & $0.0 \%$ \\
\hline Interested in certification $^{a}$ & $25.5 \%$ & $0.0 \%$ & $7.9 \%$ & $33.3 \%$ \\
\hline Not interested in certification & $56.4 \%$ & $85.7 \%$ & $71.1 \%$ & $66.7 \%$ \\
\hline
\end{tabular}

a Defined as interested in becoming certified within the next five years.

Table 4. Significant variables for predicting whether or not a company is interested in forest certification.

\begin{tabular}{|c|c|c|c|c|c|c|}
\hline Variable & Coefficient & $\begin{array}{c}\text { Wald } \\
\text { Statistic }\end{array}$ & Significance & $\begin{array}{l}\text { (Odds) } \\
\operatorname{Exp}(B)\end{array}$ & $\begin{array}{l}\text { C.I. for } \operatorname{Exp}(B) \\
\text { Lower } 95 \%\end{array}$ & $\begin{array}{c}\text { C.I. for } \operatorname{Exp}(B) \\
\text { Upper } 95 \%\end{array}$ \\
\hline Constant & 6.459 & 26.377 & 0.000 & 638.241 & - & - \\
\hline $\mathrm{B}_{1}$ & -1.260 & 17.185 & 0.000 & 0.284 & 0.156 & 0.515 \\
\hline $\mathrm{B}_{2}$ & -0.570 & 10.201 & 0.001 & 0.566 & 0.399 & 0.802 \\
\hline
\end{tabular}

$\mathrm{B}_{1}=$ "My company believes that being certified effectively differentiates our company from our competitors." Interval scale from 1 (strongly disagree) to 5 (strongly agree).

$\mathrm{B}_{2}=$ "How well does your company understand COC certification for wood products manufacturing?" Interval scale from 1 (do not understand at all) to 5 (completely understand).

readily interpreted. However, the results show that only two of the variables under study significantly affect a company's participation in forest certification (significant Wald statistics): (1) manufacturers' awareness levels of COC certification and (2) manufacturers' acceptance of forest certification as a tool for firm differentiation. Specifically, the $\operatorname{Exp}(B)$ values are interpreted to mean that, with each step along the respective five-point interval scales used to measure each variable: (1) the more strongly a company agrees that being certified will effectively differentiate it from its competitors, the odds that the company will be interested in forest certification increase by $71.6 \%$; and (2) as a company's understanding of $\mathrm{COC}$ certification increases, the odds that the company will be interested in forest certification increase by $43.4 \%{ }^{17}$.

In an attempt to better understand the motivations of companies that were either interested in forest certification (currently or planning to

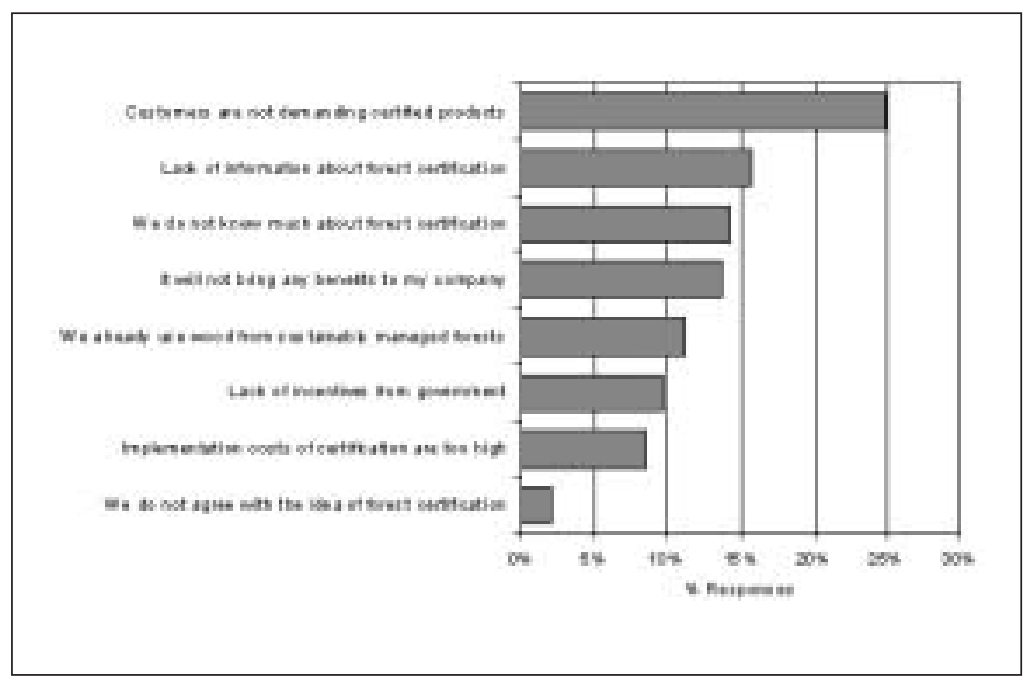

Fig. 2. Reasons for disinterest in forest certification among respondent companies (percentage of responses).

become involved) versus those that were not, the survey asked each group different questions. For instance, companies that were disinterested in forest certification $(\mathrm{n}=70)$ were asked to explain why from a list of possible reasons (Fig. 2). Almost $25 \%$ of the disinterested companies indicated that their customers are not demanding certified products. A lack of information about forest certification (15.7\%) and not knowing much about certification (14.2\%) were the second and third most commonly cited reasons, respectively. Notably, only $2.0 \%$ of these respondents actually disagreed with the idea of forest certification.

\footnotetext{
${ }^{17}$ The $\operatorname{Exp}(\mathrm{B})$ values may be more directly interpreted from Table 4 as: (1) the odds of a company not being interested in forest certification decrease by $56.6 \%$ for each step up the interval scale; and (2) the odds of a company not being interested in forest certification decrease by $28.4 \%$ for each step up the interval scale.
}

Similarly, respondents who were either currently engaged in forest certification, or interested in becoming engaged within the next five years $(\mathrm{n}=38)$, were asked to rank six possible reasons explaining their interest and/or endorsement. Fig. 3 shows the proportions of responses assigned to each rank for each of the possible reasons listed. The most important reasons explaining interest (both in terms of total responses and proportion of responses ranked first) were a concern for present and future health of forests and a belief that environmental purchasing is going to become standard practice in the future. Interestingly, minimizing external pressures from ENGOs and obtaining benefits from forest certification ranked similarly to the first two reasons in terms of total responses. However, upon closer inspection, it can be observed that the former contains a high proportion of third-place rankings and the latter a high proportion of second-place rankings. 


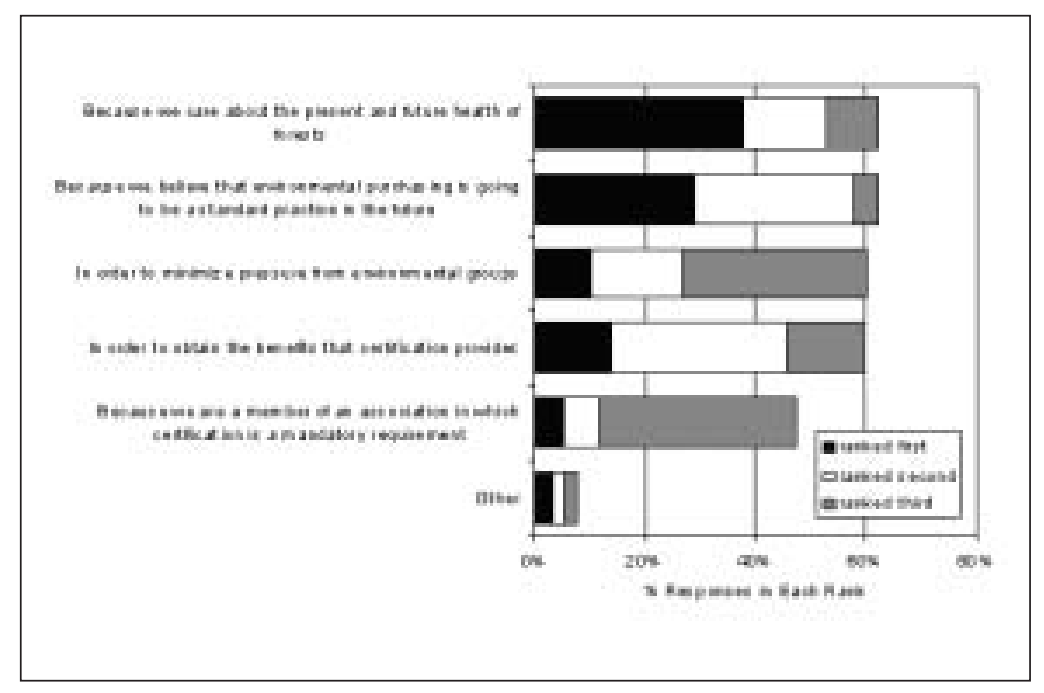

Fig. 3. Reasons for interest in forest certification among respondent companies (by proportion of responses ranked first, second, and third).

Requirements of industry associations followed these two reasons, although there was a high proportion of third-place rankings. Finally, other reasons mentioned by respondents in an open-ended question on the subject included requirements to engage in LEED (Leadership in Energy and Environmental Design) building projects. An interesting trend is noted here in that a greater emphasis seems to be placed on more global, environmental issues versus more pragmatic, business concerns as reasons for explaining an interest in forest certification.

Those companies that were interested in forest certification (certified or planning to become certified within five years) were also asked a number of questions related to certification schemes and services. For example, this sub-sample of companies was asked which forest certification scheme they were (or would like to be) involved with. Respondents primarily associated themselves with the Forest Stewardship Council (FSC), the Canadian Standards Association (CSA), and the Sustainable Forestry Initiative (SFI) at 25.8\%, 21.0\%, and $16.1 \%$ of the responses, respectively. These were followed by various other unspecified forest certification schemes at 9.7\% of the responses, the Pan European Forest Certification ${ }^{18}$ scheme (PEFC) at 4.8\%, and the American Tree Farm System (AFTS) at $3.2 \%$. It is notable that almost one-fifth (19.4\%) of the respondents in this sub-sample had not yet decided which forest certification scheme they would use. When asked what type of services forest certification organizations should be providing in the future, responding companies were fairly evenly split between public promotion $(34.3 \%$ of the responses), information on the certification process (30\%), and advice on chain of custody certification (25.7\%).

\section{Company attitudes towards forest certification}

To assess company attitudes towards forest certification, all respondent companies $(\mathrm{n}=115)$ were asked to state their level of agreement with a range of statements using a fivepoint Likert scale (from 1 = strongly disagree to $5=$ strongly

\footnotetext{
${ }^{18}$ Now known as the Programme for the Endorsement of Forest Certification.
}

agree). The results are ordered in Fig. 4 from highest to lowest levels of agreement, along with corresponding mean values and 95\% confidence intervals. This presentation allows for simple statistical comparisons of each statement against a neutral or indifferent value of 3 (at $\alpha=.05$ ).

There was significant agreement over the need for forest certification in the tropics and its potential to reduce threats to tropical forests. Respondent firms also generally reported having made organizational changes to accommodate environmental commitments, and having support for environmental improvement at the top management levels in their organizations. However, there was, on average, significant disagreement that forest certification would provide (financial) benefits such as consumer price premiums or improvements in production processes. Respondents were more neutral on issues relating to the likelihood of consumer demand for certified forest products existing in the future, forest certification being an effective differentiation tool for competing firms, and Canadian forests being threatened.

Using a K-means cluster analysis ${ }^{19}$, the underlying response patterns of these attitudinal variables were also studied to determine whether attitudinally similar segments (clusters) of the Canadian value-added wood products manufacturing sector could be uncovered and whether some segments were more receptive to forest certification than others. Based on maximum differences in cluster means, respondents' general attitudes towards forest certification segmented most clearly into three distinct clusters (Dillon and Goldstein 1984). Table 5 shows the final cluster centres (mean values for each cluster) for each attitudinal variable used in the analysis.

A series of one-way analyses of variance ${ }^{20}(\alpha=0.05)$ revealed no significant differences between the characteristics of the companies in each of the three clusters. However, a number of interesting trends emerged from the cluster analysis itself. Cluster 3 represents a small group of manufacturers (18.3\% of the sample) that harbour generally negative attitudes towards forest certification. These respondents were doubtful whether forests (Canadian or tropical) were, in fact, threatened, and whether forest certification could help reduce such threats. They expressed reluctance towards management level changes to accommodate environmental commitments, and did not anticipate any benefits or future developments associated with forest certification. Manufacturers in Cluster 2 (38.3\% of the sample) had relatively positive attitudes regarding forest certification. They expressed general agreement with the ideas that forests are threatened and that forest certification can help to ameliorate this threat. Cluster 2 respon-

\footnotetext{
${ }^{19} \mathrm{~K}$-means clustering is an empirical partitioning technique for separating data into distinct groups sharing similar characteristics, using an algorithm that can handle large numbers of cases (Dillon and Goldstein 1984, Archer et al. 2005).

${ }^{20}$ ANOVAs were performed on several variables, including proportion of sales to international versus domestic markets, number of employees, annual sales, production types, and an understanding of basic certification concepts. Details of the ANOVAs are not presented here.
} 


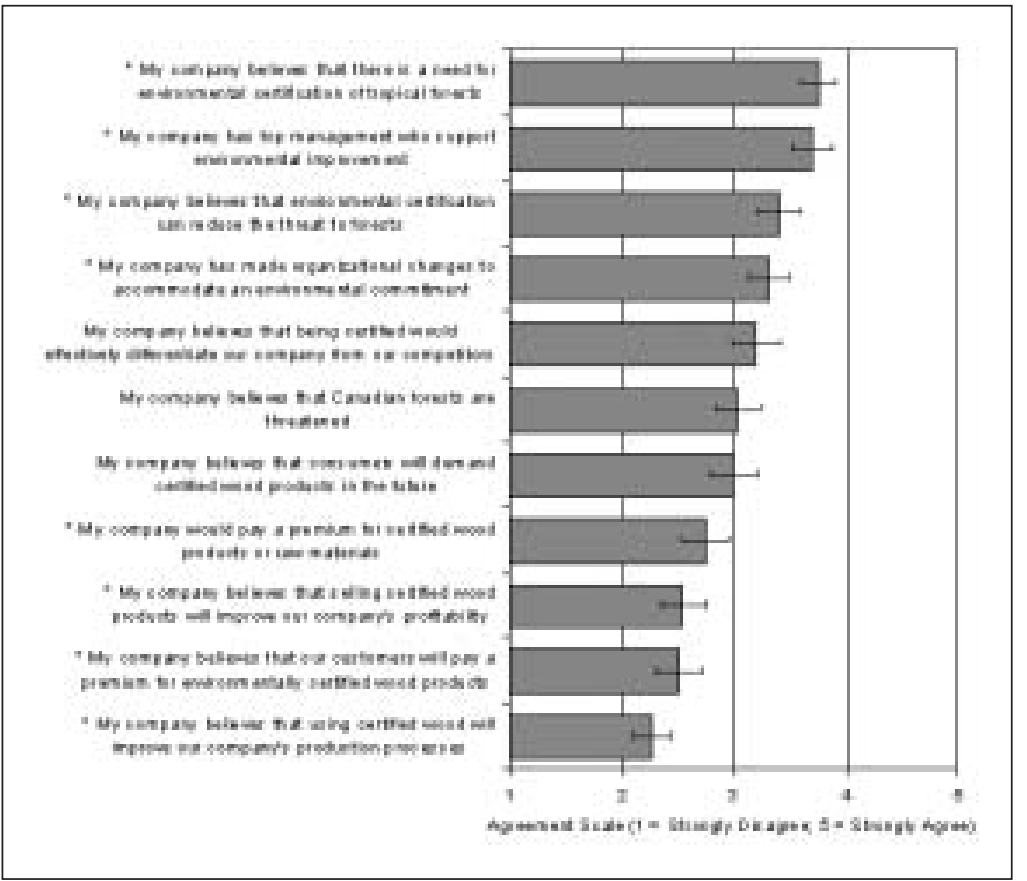

Fig. 4. Attitudes of respondent companies towards forest certification (showing means with 95\% confidence intervals; 1 = strongly disagree, 5 = strongly agree; ${ }^{*}=$ significantly different from a neutral value of 3 at $\alpha=0.05$ ).

dents also indicated interest in making management level changes to accommodate environmental commitments. While they had doubts as to whether forest certification would yield any financial or production related benefits, they did anticipate future consumer demand and believed that certification could help differentiate them from their competitors. Although manufacturers in Cluster 1 (the largest group at $43.5 \%$ of the sample) could be categorized as attitudinally neutral (midway between Clusters 2 and 3), they had generally positive perceptions of forest certification. These respondents were doubtful about Canadian forests being threatened, and the potential for forest certification to reduce such threats, but their top management appears to be willing to support environmental commitments like forest certification. They were, however, more noncommittal regarding whether forest certification would garner any price premiums, production improvements, market opportunities, or increased profitability.

\section{Challenges and benefits of forest certification}

The subset of respondents interested in forest certification $(\mathrm{n}=38)$ was also asked to identify some of the perceived challenges and benefits of certification. Fig. 5 lists the various challenges faced by companies, by frequency of responses. Costs required to become certified was identified $14.9 \%$ of the time as one of the main challenges of forest certification. Insufficient market demand was another challenge at $11.3 \%$ of the responses. Lack of certified suppliers (10.3\%), insufficient price premiums (9.7\%) and lack of information about forest certification (8.7\%) rounded out the top five challenges.

This subset of companies was also queried on the potential benefits of forest certification. Specifically, respondents were asked to rate the likelihoods of a series of potential benefits that could be derived on an interval scale (from $1=$ not at all likely to $5=$ very likely). Means were computed for each potential benefit and plotted in Fig. 6, along with 95\% confidence intervals. On average, respondent companies stated that forest certification was likely (significantly higher than a neutral value of 3 at $\alpha$ $=0.05$ ) to result in better public relations / company image, satisfaction in ensuring the sustainability of our forests, and increased market access. However, responses regarding increased profitability, better inventory control, waste reduction,

Table 5. Final cluster centres for K-means analysis on attitudes of respondent companies towards forest certification ( 1 = strongly disagree, 5 = strongly agree).

\begin{tabular}{ccc}
\multicolumn{3}{c}{ Cluster } \\
\hline 1 & 2 & 3 \\
$(\mathrm{n}=50)$ & $(\mathrm{n}=44)$ & $(\mathrm{n}=21)$
\end{tabular}

My company believes that there is a need for environmental certification in tropical forests.

$\begin{array}{ccc}4 & 4 & 3 \\ 4 & 4 & 3 \\ 3 & 4 & 3 \\ 3 & 4 & 3 \\ 3 & 4 & 2 \\ 3 & 4 & 3 \\ 3 & 4 & 2 \\ 2 & 4 & 2 \\ 2 & 3 & 1 \\ 2 & 3 & 1 \\ 2 & 3 & 1 \\ 2.82 & 3.73 & 2.18\end{array}$




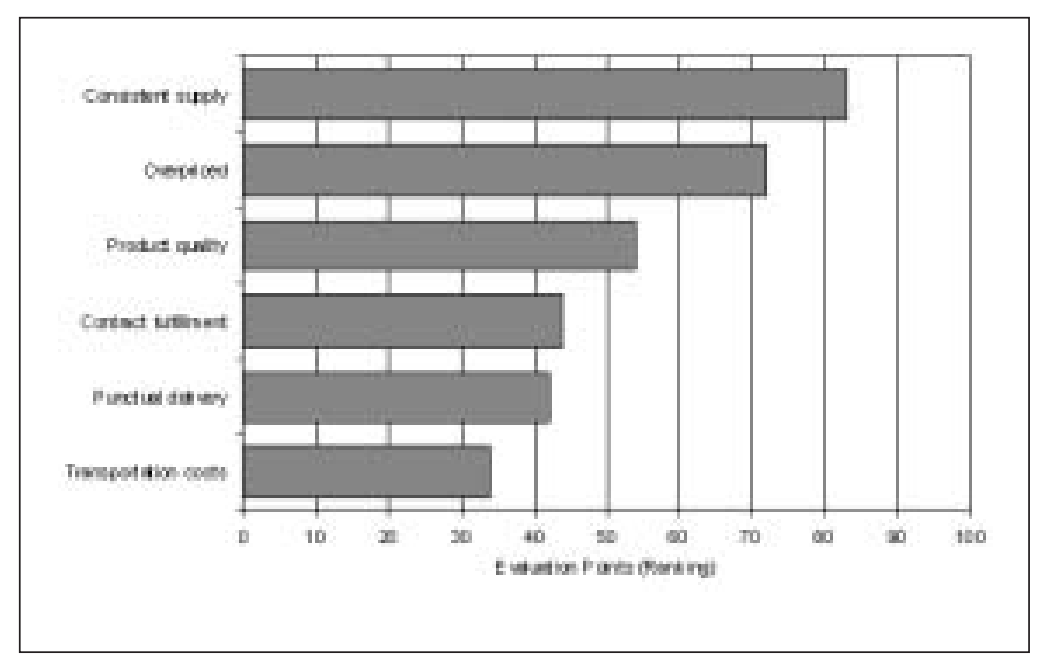

Fig. 5. Perceived challenges of forest certification among interested respondents (percentage of responses].

and increased overall efficiency indicated that companies consider these to be unlikely benefits of forest certification. Respondents were neutral, on average, with respect to forest certification contributing to improved communication with customers, reduced pressure from environmental groups, and higher price premiums. It is interesting to note that respondents anticipate increased market access to be a benefit of forest certification, but that this would not necessarily translate into increased profits or higher price premiums.

\section{Discussion}

This study reveals that forest certification has not yet been widely adopted in the Canadian value-added wood products manufacturing sector. Only $35.2 \%$ of the respondent companies plan to support forest certification within the next five years, and only half of these respondents are already involved in certification. Paradoxically, the respondents in this study generally seem to care about the health of forests and few are opposed to the idea of forest certification. Although there is a myriad of possible reasons why the majority $(64.8 \%)$ of value-added wood products manufacturers in this study are not and do not expect to be interested in forest certification in the near future, many of the challenges revolve around integrating certification into business strategies. In fact, three themes related to this appear to have emerged from this study of the value-added sector: (1) continued emphasis upon more traditional marketing approaches; (2) absence of market or compliance pressures; and (3) general knowledge gaps with respect to forest certification.

The wood products industry-most particularly commodity producers - has only recently begun to integrate forest certification into mainstream business practices as an environmental marketing tool (Menon and Menon 1997, Kärnä 2003). Despite the growing popularity of environmental marketing, the results of this study suggest that the Canadian value-added sector tends not to emphasize environmental elements in its marketing strategies, opting instead to concentrate on more traditional attributes like product quality and pricing. More generally, forest certification has not yet widely found its way into the marketing strategies of Canada's valueadded wood products manufacturers. As one respondent stated, when characterizing the company's everyday business concerns, "Value is in a service, not in the material used." Previous research has shown that companies that prioritize environmental marketing concepts are generally also the ones that are most concerned with company image (Kärnä 2003). The results here suggest that many value-added firms consider company image to be of only moderate importance.

Recognizing that forest certification is rooted in and driven by the collective environmental consciousness of consumers (Sheth and Parvatiyar 1995, Menon and Menon 1997), many firms have adopted certification as a means of accruing market benefits. However, consistent with some of the literature (Shellenberger and Nordhaus 2004, Bartley 2005), this research suggests that many Canadian value-added manufacturers do not believe there is an existing market demand for certified wood products (with the possible exception of select niche markets). Excerpts from respondent comments highlight this point: "[Our] client base expresses no interest or concern with certification."; "We had most customers that require or indicated that they may require certification no longer ask [for] or request it. The environmental movement seems to have faded somewhat."; "[The] public [is] not knowledgeable about it. [They] have no idea what this certification is all about." Even in the absence of market pressures,

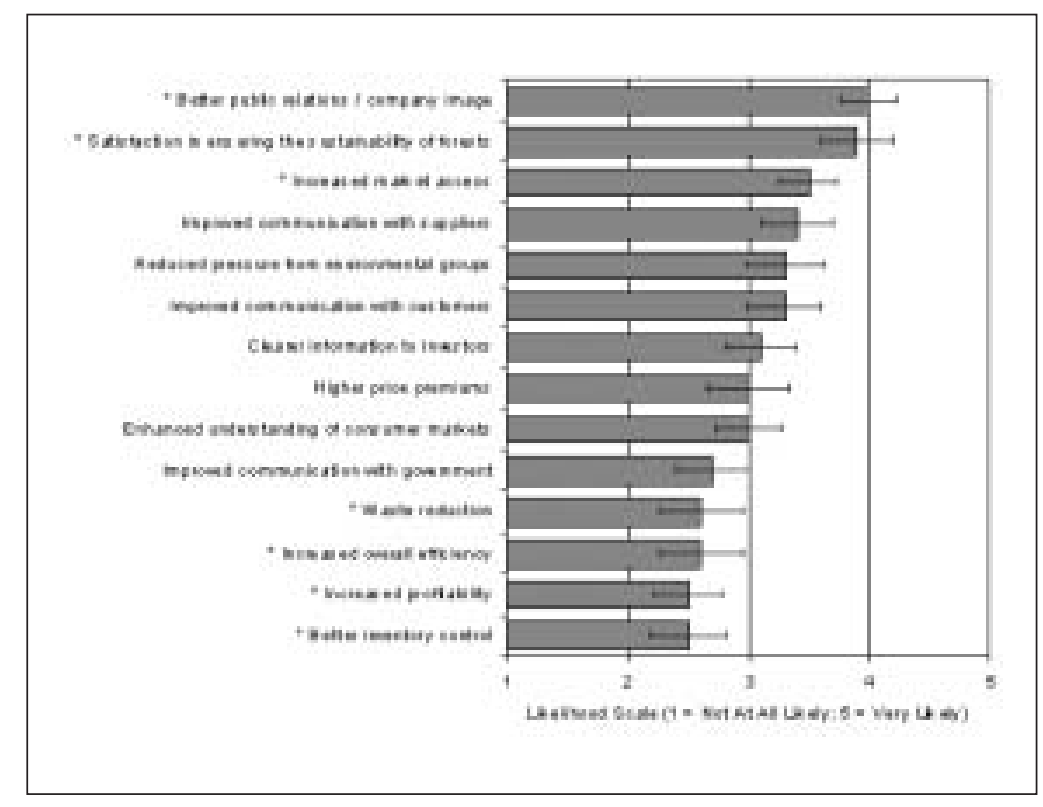

Fig. 6. Perceived benefits of forest certification (showing means with $95 \%$ confidence intervals; 1 = not at all likely, 5 = very likely; ${ }^{*}=$ significantly different from a neutral value of 3 at $\alpha=0.05$ ). 
many firms may be encouraged to adopt forest certification either in response to ENGO campaigns or as a condition of membership in industry associations (Cashore et al. 2004). However, the value-added manufacturers sampled in this study do not seem to be under much external pressure to adopt forest certification, with companies interested in certification not ranking pressures from ENGOs and industry associations particularly highly as reasons explaining their interest. However, given that ENGOs generally target firms that are larger than most value-added companies in order to influence behaviours (Cottica 1993), and that value-added manufacturers have limited representation within major industry associations like FPAC (FPAC 2006), this result is not particularly surprising.

This study also uncovered a general lack of understanding and awareness of forest certification within the Canadian value-added wood products sector. This knowledge gap was more pronounced for the majority of firms that are not interested in forest certification, with commonly cited reasons for their disinterest relating to a lack of information and knowledge. This was further confirmed by the results of the logistic regression, which suggest that higher levels of understanding of COC certification mean that a company is more likely to be interested in forest certification. The connection between generally low levels of knowledge and limited uptake of forest certification is consistent with previous research (Gronroos and Bowyers 1999; Vidal et al. 2005). It is possible, as some authors have speculated (Kärnä 2003), that these knowledge gaps are precluding Canadian value-added wood products manufacturers from adopting forest certification as part of their business and marketing strategies.

The rapid growth of forest certification seems to suggest that this mechanism is here to stay. Despite their general reluctance, there are signs that forest certification can be incorporated into the business philosophies of Canadian value-added producers, including optimistic outlooks for Canadian consumer markets for certified products (Kozak et al. 2004) and the growing popularity of the LEED system, which favours FSC-certified building products (USGBC 2005) and has the potential to become an influential driver for the adoption of certification by value-added manufacturers ${ }^{21}$. Clearly there are consumers - albeit in niche markets - who would prefer to purchase environmentally certified wood products. As one respondent put it, "We find our customers enjoy the knowledge that our wood comes from a known, well-managed source."

Given the uncertainty and even novelty (for some firms) of forest certification to many value-added manufacturers, it is not particularly unexpected that the cluster analysis uncovered a sizable group of companies (43.5\% of the sample) that have adopted a "wait and see" approach. Although manufacturers in this segment have a positive attitude toward forest certification, they seem to have put any decisions to adopt certification on hold pending future developments in markets

\footnotetext{
${ }^{21}$ As of May 2006, the US Green Building Council Board of Directors asked the LEED Steering Committee to recognize other forest certification systems like CSA and SFI in the LEED system (Gonchar 2006). While this has caused a stir within the environmental community, it appears as though these changes will take effect in the near future.
}

for certified products. One respondent explained it by noting that, "[Certification] may be a good idea and may be necessary in the future. I do not believe there is any benefit to our company at present. There are other areas that are a higher priority to our company. If necessary, we will participate at the appropriate time." Over time and with targeted promotional efforts on the part of forest certification agencies, this large segment could have a significant impact on certification uptake in Canada's value-added wood products sector. Forest certification agencies should take particular note of this result and develop targeted communications efforts at firms that are interested in becoming certified, but have yet to settle on which certification scheme they will endorse. In particular, messaging should attempt to address firms' perceptions that forest certification is prohibitively costly, market demand for certified wood products is sluggish, and supplies of certified wood raw materials are inconsistent. On this latter point, one respondent states, "Until consistency of volume, supply, quality, and price stabilize, we will not be able to offer our customers [certified] products."

For those value-added manufacturers that are either currently engaged or interested in adopting forest certification within the next five years, the overarching reasons appear to be related to moral and ethical concerns. Respondents cited concerns about the health of forests as the most important reason for seeking forest certification, while a sense of satisfaction in ensuring the sustainability of forests was seen to be one of its most important benefits. There is also a general belief that forest certification can reduce the threat to forests, especially in the tropics. These findings are consistent with environmental marketing theories which state that companies may seek environmental marketing tools, such as forest certification, on moral grounds (Menon and Menon 1997, Kärnä 2003).

Such moral convictions may, however, disappear in the face of diminishing profits. While firms seem to agree that their top management supports environmental improvement, there is also a general sense that the direct benefits derived from forest certification may not necessarily be realized as short-term financial gains in the forms of increased profitability, price premiums, and improved production processes. However, the logistic regression in this analysis provides some evidence to suggest that forest certification can possibly be used as an effective differentiation strategy in Canada's increasingly competitive value-added wood products sector.

\section{Conclusions}

As a business strategy, forest certification plays the dual role of promoting sustainable forest management (SFM) practices and the environmental attributes of forest products derived from such practices. From a marketing perspective, scientific knowledge regarding manufacturers' acceptance of forest certification is crucial, but remains very limited, particularly in the Canadian value-added wood products manufacturing sector.

This study found limited support among Canadian valueadded wood products manufacturers for forest certification. Currently, only $17.6 \%$ of the sector is involved in forest certification and another $17.6 \%$ plans to become involved within the next five years. In the meantime, the majority $(64.8 \%)$ of the sector voiced a distinct lack of interest in forest certification. 
Three main reasons for low levels of participation in forest certification emerged from the results of this study: (1) a propensity on the part of value-added manufacturers to concentrate on more traditional aspects of marketing wood products, like price and quality; (2) the perception that there is limited or no consumer demand and very little in the way of other compliance pressures; and (3) a general lack of knowledge about forest land and chain of custody (COC) certification. Companies that have adopted, or are interested in adopting, forest certification as a business strategy tend largely to be driven by issues of ethics and sustainability. In this study, such respondents generally believe that forest certification will help them to contribute to ensuring forest health, while concurrently improving their company images and market reach However, it is notable that these firms do not necessarily expect forest certification to provide any production-related or financial benefits, such as price premiums. That said, past studies suggest that forest certification can effectively be used as a competitive differentiation tool in the marketplace and the value-added manufacturers in this study that were interested in forest certification generally believed this to be the case.

The results also show that distinct clusters of Canadian value-added wood producers exist with respect to company attitudes towards forest certification. While some firms are distinctly opposed to the idea of forest certification, two sizable segments either favour it or have adopted a more prudent "wait and see" approach. Awareness of forest certification concepts was higher in this "wait and see" group, whose future involvement in certification will depend, in large part, on the "market buzz" that certification manages to create among consumers of value-added wood products. These firms pose an interesting target group for further investigation into the promotion of forest certification.

Overall, this study indicates that forest certification is still in its infancy in the Canadian value-added wood products manufacturing sector. Its future likely depends on developments in manufacturer knowledge and consumer markets for certified value-added wood products. To that end, further research on methods for increasing awareness among both manufacturers and consumers is needed. However, research on the motivational drivers behind companies seeking forest certification, cost issues, and means for improving understanding of COC certification issues is also recommended.

\section{Acknowledgements}

The authors would like to acknowledge the financial support of the Sustainable Forest Management Network (A Network of Centres of Excellence).

\section{References}

Abusow, K. 2003. Canadian Forest Management Certification Status Report. Report prepared for the Canadian Sustainable Forestry Certification Coalition, Ottawa.

Abusow, K. 2006. Certification Similarities and Achievements: Summary Comparison of Forest Certification Standards in Canada. Document prepared for Forest Products Association of Canada, Ottawa [online]. Available from http://www.certificationcanada.org/ english/developments/ [cited June 2006].

Armstrong, J. and T. Overton. 1977. Estimating Non-Response Bias in Mail Surveys. Journal of Marketing Research 14: 396-402.
Anderson, R and E. Hansen. 2004. The Impact of Environmental Certification on Preferences for Wood Furniture: A Conjoint Analysis Approach. Forest Products Journal 54(3): 42-50.

Archer, H., R. Kozak and D. Balsillie. 2005. The impact of forest certification labelling and advertising: An exploratory assessment of consumer purchase intent in Canada. The Forestry Chronicle 81(2): 229-244.

Babbie, E. 2001. Practice of Social Research. $9^{\text {th }}$ ed. Wadsworth Thompson Learning, Belmont, CA.

Bass, S. 1997. Introducing Forest Certification. A Report prepared for the Forest Certification Advisory Group (FCAG) for DGVIII of the European Commission. European Forest Institute Discussion Paper 1.

Bartley, T. 2005. Institutional Emergence in an Era of Globalization: The Rise of Environmental and Social Certification Systems. Working Paper, Indiana University, Bloomington, IN [online]. Available from http://www.indiana.edu/ tbsoc/ [cited June 2006].

Bass, S. and M. Simula. 1999. Independent Certification / Verification of Forest Management. Background Paper for the World Bank/ WWF Alliance Workshop, Washington D.C.

Bass, S., K. Thornber, M. Markopoulos, S. Roberts and M. GriegGran. 2001. Certification's Impacts on Forests, Stakeholders and Supply Chain [online]. Available from http://www.iied.org/ docs/flu/psf/psf_certification.pdf [cited September 2003].

Bigsby, H. and L. Ozanne. 2002. The Purchase Decision: Consumers and Environmentally Certified Wood Products. Forest Product Journal 52(7/8): 100-105.

Boyd, H.W., R. Westfall and F. Stasch. 1989. Marketing Research: Text and Cases. Irwin, Homewood, IL.

Bull, G., S. Nilsson, J. Williams, E. Rametsteiner, T.Hammett and W. Mabee. 2001. Wood Procurement Policy: An Analysis of Critical Issues and Stakeholders. The Forestry Chronicle 77(2): 325-340.

Carson, R. 1962. Silent Spring. Houghton Mifflin Co., Boston, MA. Cashore, B. 2002. Legitimacy and the Privatization of Environ-mental Governance: How Non-State Market-Driven (NSMD) Governance Systems Gain Rule Making Authority. Governance: An International Journal of Policy, Administration and Institutions 15(4): 503-529.

Cashore, B., G. Auld and D. Newsom. 2004. Governing Through Markets: Forest Certification and the Emergence of Non-State Authority. Yale University Press, New Haven, CT.

Cashore, B., C. van Kooten, I. Vertinsky, G. Auld and J. Affolderbach. 2005. Private or Self-Regulation? A Comparative Study of Forest Certification Choices in Canada, the United States and Germany. Forest Policy and Economics 7(1): 53-69.

Cottica, A. 1993. The Economics of Green Consumerism (English translation of: L'Economia del Consumismo Verde). Annali della Fondazione Einaudi, Vol. XXVII.

Dennis, W. 2003. Raising Response Rate in Mail Surveys of Small Business Owners: Results of an Experiment. Journal of Small Business Management 41(3): 278-295.

Dillman, D.A. 1978. Mail and Telephone Surveys: The Total Design Method. John Wiley and Sons, New York, NY.

Dillon, W. and M. Goldstein. 1984. Multivariate Analysis: Methods and Applications. John Wiley and Sons, New York, NY.

Ervin, C. 2002. Special LEED Section: Measuring the Success of the LEED System. Environmental Design and Construction [online]. Available from http://www.edcmag.com/CDA/ArticleInformation/ features/BNPFeaturesItem/0,4120,80479,00.html [cited January 2005].

Field, A. 2000. Discovering Statistics: Using SPSS for Windows. Sage Publications Ltd., London, UK.

Forsyth, K., D. Haley and R. Kozak. 1999. Will Consumers Pay More for Certified Wood Products? Journal of Forestry 97(2):18-22.

FPAC. 2006. Forest Products Association of Canada: Who We Are Member Companies [online]. Available from http://www.fpac.ca/ en/who_we_are/member_companies/ [cited June 2006]. 
Gonchar, J. 2006. Proposed LEED Changes Intensify Debate over Recognition of Wood Certification Systems. GreenSource - The Magazine of Sustainable Design [online]. Available from http:// archrecord.construction.com/features/green/archives/0607dignews-1. asp [cited October 2006].

Gronroos, J. and J. Bowyers. 1999. Assessment of the Market potential for Environmentally Certified Wood Products in New Homes in Minneapolis / St. Paul and Chicago. Forest Product Journal 49(6): 28-33.

Groves, M., F. Miller and R. Donovan. 1996. Chain of Custody. In V.M. Viana, J. Ervin, R.Z. Donovan, C. Elliott and H. Gholz (eds.). Certification of Forest Products: Issues and Perspectives. Island Press, Washington D.C.

Hansen, E. 1997. Forest Certification and its Role in Marketing Strategy. Forest Products Journal 47(3):16-22.

Hansen, E. and H. Juslin. 1999. The Status of Forest Certification in the ECE Region. United Nations Publication (UNECE/FAO) $\mathrm{ECE} / \mathrm{TIM} / \mathrm{DP} / 14$

Hansen, E. and J. Punches. 1999. Developing Markets for Certified Forest Products: A Case Study of Collins Pine Company. Forest Products Journal 49(1): 30-35.

Hart, S. and G. Ahuja. 1997. Does it Pay to be Green? Business Strategy and the Environment 5(1): 30-37.

Hubbard, S. and S. Bowe. 2004. Putting Value on Certified Forest Products: Views from Wisconsin. Wood and Wood Products (July 2004): 57-62.

Humphries, S., R. Vlosky and D. Carter. 2001. Certified Wood Products Merchants in the United States: A Comparison between 1995 and 1998. Forest Products Journal 51(6): 32-38.

IBM Business Consulting Services. 2003. A Greenward Shift in the Market for Forest Products from British Columbia. IBM Business Consulting Services [online]. Available from http://www. forestethics.org/pdf/Greenward_report.pdf [cited November 2004]. Industry Canada / Strategis. 2006. Canadian Industry Statistics: Manufacturing Production - Other Wood Product Manufacturing [online]. Available from http://strategis.ic.gc.ca/canadian_industry_statistics/cis.nsf/IDE/cis3219prde.html [cited June 2006].

Jensen, K., P. Jakus, B. English and J. Menard. 2003. Market Participation and Willingness to Pay for Environmentally Certified Products. Forest Science 49(4): 632-641.

Kärnä, J. 2003. Environmental Marketing Strategy and its Implementation in Forest Industries. Academic Dissertation, University of Helsinki, Department of Forest Economics.

Kozak, R., D. Cohen, J. Lerner and G. Bull. 2004. Western Canadian Consumer Attitudes toward Certified Value-Added Wood Products: An Exploratory Assessment. Forest Products Journal 54(9): 21-24.

Kozak, R. and T. Maness. 2001. Quality Assurance for Value-Added Wood Producers in British Columbia. Forest Products Journal 51(6): 47-55.

Lambert, D. and T. Harrington. 1990. Measuring Nonresponse Bias in Customer Service Mail Surveys. Journal of Business Logistics 11(2): 5-23.

Libby, B. 2004. LEED Green-Building Standards Travel to Canada [online]. Available from http://www.metropolismag.com/cda/ story.php?artid=684 [cited November 2004].

McGuire, W.J. 1985. Attitudes and Attitude Change. In G. Lindzey and E. Aronson (eds.). Handbook of Social Psychology. $3^{\text {rd }}$ ed. Random House, New York, NY.

Menard, S. 2002. Applied Logistic Regression Analysis. $2^{\text {nd }}$ ed. Sage Publications, Inc. Thousand Oaks, CA.

Menon, A. and A. Menon. 1997. Environmental Marketing Strategy: The Emergence of Corporate Environmentalism as Market Strategy. Journal of Marketing 61(January): 51-67.

Mentzer, J., W. Dewitt, J.S. Keebler, S. Min, N. Nix and C.D. Smith. 2001. What is Supply Chain Management? In J. Mentzer (ed.). Supply Chain Management. Sage Publications, Inc.
Miller, H. 2002. Manufactures Seeing Green. Wood and Wood Products 107(9): 42-50.

Ozanne, L. and R. Vlosky. 1997. Willingness to Pay for Environmentally Certified Wood Products: The Consumer Perspective. Forest Products Journal 47(6): 39-48.

Prakash, A. 2002. Green Marketing, Public Policy and Managerial Strategies. Business Strategy and the Environment 11(5): 285-297.

Read, M. 1991. An Assessment of Claims of "Sustainability" Applied to Tropical Wood Products and Timber Retailed in the United Kingdom, July 1990-January 1991. World Wide Fund for Nature, London, UK.

Ronit, K. 2001. Institutions of Private Authority in Global Governance. Linking Territorial Forms of Self-Regulation. Administration and Society. 33(5): 555-578.

Sale, K. 1993. The Green Revolution: American Environmental Movement, 1962-1992. Hill and Wang, New York, NY.

Sheth, J. and A. Parvatiyar. 1995. Ecological Imperative and the Role of Marketing. In M. Polonsky and A. Mintu-Wimsatt (eds.). Environmental Marketing: Strategies, Practice, Theory and Research. The Haworth Press, Inc. New York, NY.

Shellenberger, M. and T. Nordhaus. 2004. The Death of Environmentalism: Global Warming Politics in a Post-Environmental World. Breakthrough Institute [online]. Available from http://www. thebreakthrough.org/images/Death_of_Environ-mentalism.pdf [cited June 2006].

Spinazze, M. and S. Kant. 1999. Market Potential for Certified (Wood) Products in Ontario, Canada. The Forestry Chronicle 75(1): 39-48.

Tabachnick, B. and L. Fidell. 2001. Using Multivariate Statistics. $4^{\text {th }}$ ed. Allyn and Bacon, Pearson Education Company, Needham Heights, MA.

Takahashi, T., G. van Kooten and I. Vertinsky. 2003. Why Might Forest Companies Certify? Results from a Canadian Survey. International Forestry Review 5(5): 329-337.

UNECE/FAO. 2003. Forest Products Annual Market Analysis, 2002-2004 (Timber Bulletin LVI(2003), No.3) [online]. Available from http://www.unece.org/trade/timber/docs/fpama/2003/fpama 2003a.htm [cited January 2005].

USGBC. 2005. U.S. Green Building Council Website [online]. Available from http://www.usgbc.org/LEED/leed_interiors.asp [cited January 2005].

Veisten, K. 2002. Potential Demand for Certified Wood Products in the United Kingdom and Norway. Forest Science 48(4): 767-778.

Vidal, N., R. Kozak and D. Cohen. 2005. Chain of Custody Certification: An Assessment of the North American Solid Wood Sector. Forest Policy and Economics 7(3): 345-355.

Vlosky, R., R. Gazo and D. Cassens. 2003. Certification Involvement by Selected United States Value-Added Solid Wood Products Sectors. Wood and Fiber Science 35(4): 560-569.

Vlosky, R. and L. Ozanne. 1998. Environmental Certification of Wood Products: The US Manufacturers' Perspective. Forest Product Journal 48(9): 21-26.

Wilson, E. 1999. Research Practice in Business Marketing: A Comment on Response Rate and Response Bias. Industrial Marketing Management 28(1999): 257-260.

WMC. 2006. Wood Manufacturing Council: Sector Profile [online]. Available from http://www.wmc-cfb.ca/aboutus/sectorprofile.htm [cited June 2006].

World Resource Institute (WRI). 2005. World Resource Institute EarthTrends Environmental Information: Forest Area Certified by All Certification Schemes [online]. Available from http://earthtrends.wri.org [cited January 2005].

World Wildlife Fund for Nature (WWF). 2000. The Forest Industry in the $21^{\text {st }}$ Century. Report prepared by the WWF's Forests for Life Campaign [online]. Available from http://www.panda.org/forests 4life [cited January 2003]. 